\title{
EIGHTH INTERIM STATUS REPORT: MODEL 9975 PCV O-RING FIXTURE LONG-TERM LEAK PERFORMANCE
}

\author{
W. L. Daugherty \\ Savannah River National Laboratory \\ Materials Science \& Technology
}

Publication Date: August 2013

Savannah River Nuclear Solutions

Savannah River Site

Aiken, SC 29808

This document was prepared in conjunction with work accomplished under Contract No. DE-AC09-08SR22470 with the U.S. Department of Energy. 


\section{DISCLAIMER}

This work was prepared under an agreement with and funded by the U.S. Government. Neither the U. S. Government or its employees, nor any of its contractors, subcontractors or their employees, makes any express or implied: 1. warranty or assumes any legal liability for the accuracy, completeness, or for the use or results of such use of any information, product, or process disclosed; or 2. representation that such use or results of such use would not infringe privately owned rights; or 3. endorsement or recommendation of any specifically identified commercial product, process, or service. Any views and opinions of authors expressed in this work do not necessarily state or reflect those of the United States Government, or its contractors, or subcontractors. 


\section{Eighth Interim Status Report: Model 9975 PCV O-Ring Fixture Long-Term Leak Performance}

\section{APPROVALS:}

W. L. Daugherty

Date

Author, Materials Science and Technology

T. E. Skidmore

Date

Technical Review, Materials Science and Technology

K. A. Dunn

Date

Pu Surveillance Program Lead, Materials Science and Technology

G. T. Chandler

Date

Manager, Materials App \& Process Tech

E. R. Hackney

Date

NMM Engineering

\section{REVIEWS:}

D. R. Leduc

Date

Savannah River Packaging Technology 


\section{Revision Log}

Document No. SRNL-TR-2013-00151 Rev. No. 0

Document Title Eighth Interim Status Report: Model 9975 PCV O-Ring Fixture Long-Term Leak Performance

Rev. \# Page \# Description of Revision Date

$\begin{array}{lll}0 & \text { all Original document }\end{array}$ 


\section{$\underline{\text { Summary }}$}

A series of experiments to monitor the aging performance of Viton ${ }^{\circledR}$ GLT O-rings used in the Model 9975 package has been ongoing since 2004 at the Savannah River National Laboratory. Seventy tests using mock-ups of 9975 Primary Containment Vessels (PCVs) were assembled and heated to temperatures ranging from 200 to $450{ }^{\circ} \mathrm{F}$. They were leak-tested initially and have been tested periodically to determine if they meet the criterion of leak-tightness defined in ANSI standard N14.5-97. Fourteen additional tests were initiated in 2008 with GLT-S O-rings heated to temperatures ranging from 200 to $400{ }^{\circ} \mathrm{F}$.

High temperature aging continues for 23 GLT O-ring fixtures at $200-270{ }^{\circ} \mathrm{F}$. Room temperature leak test failures have been experienced in all of the GLT O-ring fixtures aging at $350{ }^{\circ} \mathrm{F}$ and higher temperatures, and in 8 fixtures aging at $300{ }^{\circ} \mathrm{F}$. The remaining GLT O-ring fixtures aging at $300{ }^{\circ} \mathrm{F}$ have been retired from testing following more than 5 years at temperature without failure. No failures have yet been observed in GLT O-ring fixtures aging at $200{ }^{\circ} \mathrm{F}$ for 61 - 85 months, which is still bounding to O-ring temperatures during storage in $\mathrm{K}$ Area Complex (KAC). Based on expectations that the fixtures aging at $200{ }^{\circ} \mathrm{F}$ will remain leaktight for a significant period yet to come, 2 additional fixtures began aging in 2011 at an intermediate temperature of $270^{\circ} \mathrm{F}$, with hopes that they may reach a failure condition before the $200{ }^{\circ} \mathrm{F}$ fixtures.

High temperature aging continues for 6 GLT-S O-ring fixtures at $200-300{ }^{\circ} \mathrm{F}$. Room temperature leak test failures have been experienced in all 8 of the GLT-S O-ring fixtures aging at 350 and $400{ }^{\circ} \mathrm{F}$. No failures have yet been observed in GLT-S O-ring fixtures aging at 200 $300{ }^{\circ} \mathrm{F}$ for 41 - 45 months.

Aging and periodic leak testing will continue for the remaining PCV fixtures.

\section{Background}

This is an interim status report for experiments carried out per Task Technical Plans WSRC-TR2003-00325 [1] and SRNS-TR-2008-00054 [2], which are part of the comprehensive 9975 package surveillance program [3].

PCV test fixtures were assembled with either Parker Seals V0835-75 (hereafter referred to as Viton ${ }^{\circledR}$ GLT) O-rings or Parker Seals VM835-75 (hereafter referred to as Viton ${ }^{\circledR}$ GLT-S) Orings, and are being aged in environments that provide varying degrees of margin over KAC storage conditions. The purpose of these experiments is to characterize the performance of the O-ring seals, and then correlate the data to lifetime predictions of PCV and SCV O-ring seals in 9975 packages being stored in KAC. O-ring performance in these tests is defined by leaktightness, per ANSI standard N14.5-97 at room temperature.

The data from these fixtures are scoping in nature, although most of the controls under which they were collected are typical of baseline data. Accordingly, care should be used to assess the overall quality of the data prior to use in baseline applications. Within the 9975 surveillance program, these data will be used for information only, to compare to baseline data from other testing and build confidence in the overall predictions of O-ring service life. 


\section{Experimental Method}

\section{Test Matrix}

Testing has evolved to include 3 test matrices. These address Viton ${ }^{\circledR}$ GLT O-rings aged at 200 or $300{ }^{\circ} \mathrm{F}$, Viton ${ }^{\circledR}$ GLT O-rings aged at $270-450{ }^{\circ} \mathrm{F}$, and Viton ${ }^{\circledR}$ GLT-S O-rings aged at $200-$ $400{ }^{\circ} \mathrm{F}$.

The first test matrix was developed to determine the importance and effect of several variables on the condition of the PCV O-rings over time inside the KAC storage facility. The variables believed to be the most relevant to O-ring performance in storage were O-ring temperature, radiation/dose rate, O-ring lubrication, and internal PCV atmosphere (internal PCV atmosphere was subsequently dropped as a test variable). Two different dose rates were selected to evaluate potential dose rate effects. A total of 62 tests, with 22 separate sets of conditions were developed. Replicates of tests were developed based on a modified full-factorial statistical design. The test variables and the basis for variable selection are given in Table 1.

The interior of the test fixture is accessible through a tube connected to the bottom. This tube includes a $\mathrm{T}$ connection to facilitate leak testing of both O-rings simultaneously or separately. With this arrangement, data are obtained on both O-rings installed in each fixture. Although only the outer O-ring is credited for containment, testing both provides twice the information under nearly identical conditions.

Several fixtures have been removed from the first test matrix since the initiation of the study. Eleven were removed from test based on leak test performance while at their conditioning temperature of $200{ }^{\circ} \mathrm{F}$ or $300{ }^{\circ} \mathrm{F}$ and they were disassembled and examined. Fourteen more were taken out of test after a power failure caused a temperature excursion severe enough to invalidate the tests. One additional fixture was removed from test in 2007 for reasons that were not documented. Fixture 62 was returned to service briefly with new O-rings in 2007, and designated 62-2007. Further details of these fixtures are provided in Reference 4. Several fixtures conditioning at $300{ }^{\circ} \mathrm{F}$ have experienced room temperature O-ring leakage (i.e. failed), beginning in April 2010. The status of each fixture, along with its test parameters, is summarized in Table 2.

Fixtures in the first test matrix were initially leak tested on a nominal 6-month schedule. Once the first of these began failing the room temperature leak test, the test frequency for fixtures heated to $300^{\circ} \mathrm{F}$ was increased to every 3 months.

In the second test matrix, five fixtures were placed into test in October 2008 with new Viton ${ }^{\circledR}$ GLT O-rings. These fixtures were aged at temperatures ranging from 350 to $450{ }^{\circ} \mathrm{F}$. They were intended to provide some O-ring failures in a shorter time frame to enhance the predictive value of the original test matrix and to determine the time to failure at the "continuous" service temperature rating $\left(400{ }^{\circ} \mathrm{F}\right)$. The predictive model assumes that the time to leakage at all temperatures is a function of a common mechanism. With the expectation that these would fail 
in a much shorter time than the original fixtures, they were leak tested on a nominal 3 week frequency.

An additional two fixtures with Viton ${ }^{\circledR}$ GLT O-rings were added to the second test matrix in April 2011, and began aging at $270{ }^{\circ} \mathrm{F}$. With leak test failures experienced at aging temperatures of $300{ }^{\circ} \mathrm{F}$ and above, and no failures projected to occur at $200{ }^{\circ} \mathrm{F}$ for many years yet, it was anticipated that these two intermediate temperature fixtures might experience leak failures sooner that the $200{ }^{\circ} \mathrm{F}$ fixtures. This would provide additional confirmation of the extrapolation model for leak test data at an earlier date than the $200^{\circ} \mathrm{F}$ fixtures.

All of the second matrix fixtures were assembled with the normal O-ring lubricant and contained no backfill gas (i.e. filled with air). Three of them (one each at 350, 400 and $450{ }^{\circ} \mathrm{F}$ ) were irradiated to $2 \mathrm{E} 5 \mathrm{rad}$ at a high dose rate (approximating a 10-year service dose at a bounding rate of $2 \mathrm{rad} / \mathrm{hr})$.

The third test matrix repeats much of the variety of the first two matrices with Viton ${ }^{\circledR}$ GLT-S Orings, but on a smaller scale. Fewer fixtures were used for this alternate O-ring material since it is expected they will demonstrate the same parametric variations as the GLT O-rings. Seven separate sets of conditions were developed, and tested in duplicate for a total of 14 fixtures. The status of these fixtures, along with their test parameters, is summarized in Table 2.

\section{Initial Assembly and Setup}

The two-piece lid of the mock-up PCV, consisting of the cone seal nut and cone seal plug, was machined to be identical to the actual PCV lid. The body of the mock-up PCV was shortened to 3.5 inches from the original design of 18.6 inches and a threaded hole was machined in the bottom to provide a port for evacuating and filling the vessel with gas and for in-situ leak testing of the O-rings. A PCV test fixture with the O-rings installed in the lid is shown in Figure 1.

The mock-up PCV fixtures were assembled per the requirements described in the 9975 Safety Analysis Report for Packaging (SARP) [5]. After installation of the O-rings and assembly of the mock-up PCV test fixture, an initial leak test was performed while the fixture was at room temperature to verify leak-tightness to $1 \mathrm{E}-7 \mathrm{ref} \cdot \mathrm{cc} / \mathrm{sec}$ air or better. If the fixture required irradiation, it was placed in a Co-60 gamma cell and irradiated at one of two dose rates to reach a total dose of $2 \mathrm{E} 5 \mathrm{rad}$. This is equivalent to a ten year dose at the bounding dose rate expected for the PCV O-rings (2 rad/hr). The fixture was irradiated at either a "slow" dose rate of approximately 667 to $830 \mathrm{rad} / \mathrm{hr}$ or a faster rate of $\sim 1.7 \mathrm{E} 5 \mathrm{rad} / \mathrm{hr}$. After irradiation, the fixture was leak tested again while at room temperature, and heated to test temperature.

The vessels are heated with a flexible, wound-wire heater wrapped around the vessel circumference. Ceramic fiberboard and fiber batting are used to insulate the exposed ends of the fixtures. Stainless steel tubing is attached to the port on the top of the fixture lid via a highpressure fitting and to the hole machined into the bottom of the PCV body. A thermal fuse was added to each heater to prevent excessive temperature excursions. The heaters are controlled by a desktop computer running LabView ${ }^{\mathrm{TM}}$ software, with feedback via a type-K thermocouple attached to the PCV body. The final assembled fixture is shown in Figure 2. 


\section{Fixture Leak Testing}

The O-ring fixtures are leak-tested after initial setup, after irradiation, and periodically thereafter to the same leak-tight criterion as the 9975 PCV and SCV. The outer O-rings of the 9975 PCV and SCV are credited with being leak-tight while in transport and are credited with maintaining containment while in storage in the $\operatorname{KAC}[1,5]$.

A room temperature leakage rate of no more than $1 \mathrm{E}-7 \mathrm{ref} \cdot \mathrm{cc} / \mathrm{sec}$ air $(2 \mathrm{E}-7 \mathrm{cc} / \mathrm{sec} \mathrm{He}$ ) demonstrates leak-tightness when measured according to the requirements outlined in ANSI Standard N14.5-97 [6]. Initially, fixtures were also tested at their conditioning temperature. These additional tests were discontinued, as discussed previously [4].

Leak testing is conducted using a Varian 959 helium mass spectrometer leak detector. A gas filled envelope test, as defined in ANSI N14.5-97 Section A.5.3 is used for the mock-up PCV fixtures. Both O-rings are tested simultaneously, with failure of either O-ring causing a failure of the test. Although this approach differs from annual certification testing, it gives results that are valid and comparable [6], and accommodates the difference in set up of the actual PCV and SCV and the mock-up PCV fixture. If a leak is found, it is possible to determine which O-ring is leaking by selectively directing the helium to either the fixture body or the closure weep hole, thus testing one O-ring at a time.

The O-ring fixture leak test program was reviewed in December 2008, prompting reconsideration of the methodology used for leak testing the mock-up PCV fixtures. One important change that was made in the conduct of the leak test involved extending the test duration until permeation of helium through the O-ring was detected [7].

Observing a permeation signal for each test provides positive evidence that the fixture and test setup are capable of transmitting a helium signal (i.e. no part of the flow path is blocked), and that helium was actually introduced into the fixture. Once a permeation signal was observed for each fixture (the permeation response is described in Reference 7), subsequent testing is conducted without the extended duration to demonstrate permeation, since no actions are performed that might disrupt the flow path during aging and leak testing. All fixtures in test since December 2008 have demonstrated permeation.

\section{$\underline{\text { Results }}$}

PCV fixtures have been assembled and aged to identify the time to failure of GLT O-rings (70 tests), and GLT-S O-rings (14 tests). This report summarizes results for these fixtures through July 10, 2013.

A total of 23 GLT O-ring fixtures and 6 GLT-S O-ring fixtures remain in test. All of the GLT O-ring fixtures conditioning at $200{ }^{\circ} \mathrm{F}$ have remained leak-tight at room temperature, with total times at temperature ranging from 61 to 85 months (at the time of their last leak test). Two fixtures began conditioning at $270{ }^{\circ} \mathrm{F}$ in 2011. They have remained leak-tight at room temperature, with total time at temperature of 12 months (at the time of their last leak test). 
Eight GLT fixtures conditioning at $300{ }^{\circ} \mathrm{F}$ were retired from test in July 2012 with exposure times ranging from 61 to 74 months. Each was given a final leak test, and permeation of helium through the O-rings was re-verified. In one of these fixtures (fixture 30) the inner O-ring had failed, but the outer O-ring remained leak-tight. GLT O-rings in the remaining fixtures aging at $300{ }^{\circ} \mathrm{F}$ and higher failed previously, as noted in prior status reports. The times to failure for each GLT O-ring fixture are summarized in Table 3. Leak rate histories can be found in Table 4 for fixtures in test since the last status report [8].

All of the GLT-S O-ring fixtures conditioning at $200{ }^{\circ} \mathrm{F}, 250{ }^{\circ} \mathrm{F}$, and $300{ }^{\circ} \mathrm{F}$ have remained leaktight at room temperature, with total times at temperature of 41 to 45 months. GLT-S fixtures conditioned at $350{ }^{\circ} \mathrm{F}$ and at $400{ }^{\circ} \mathrm{F}$ failed as noted in previous status reports. The times to failure for each GLT-S O-ring fixture are summarized in Table 3. Detailed leak rate histories can be found in Table 4 for fixtures in test since the last status report [8].

\section{$\underline{\text { Discussion }}$}

In July 2012, there were 9 remaining fixtures with GLT O-rings conditioning at $300{ }^{\circ} \mathrm{F}$. These were given a final leak test, and retired from test. During the final leak test, one of these fixtures (fixture 33 inner O-ring only, the outer O-ring had previously failed) failed the leak test, and the remaining 8 were still leak-tight. Aging times for these fixtures ranged from 61 to 74 months. It was reasoned that the continued aging of these fixtures would no longer contribute to extending the O-ring service life since O-rings aged at $300{ }^{\circ} \mathrm{F}$ had previously failed after exposure times as short as 34 months. The failed fixture (\#33), and 3 of the other eight fixtures (\# 7, 30 and 52) have been opened for a final examination, while the rest are being maintained as-is for potential future test initiatives.

Each of the 4 fixtures most recently opened exhibited similar characteristics, including O-rings very square (conforming to their groove) and tight in the groove, and stains and residue left adhering to the plug and body (see Figures 3-5). These characteristics were more pronounced in the 3 fixtures that had not failed than in fixture 33 that had failed. Aside from the tearout observed on the O-rings, which likely resulted during removal, there was no obvious indication of defect or cause of failure.

The dimensional measurements were used to calculate compression set. The measurements were taken within 30 minutes of removal, and again after 12 and 30 days. These measurement intervals are generally consistent with that used previously on other fixtures. Compression set values are calculated per ASTM D395 Method B and are summarized in Table 5.

Sufficient data are available to compare the time to failure for GLT and GLT-S O-rings at 3 temperatures. At $400{ }^{\circ} \mathrm{F}$, most of the GLT-S O-ring fixtures remained leak-tight longer than the GLT O-ring fixtures. At $350{ }^{\circ} \mathrm{F}$, the trend was reversed, with 3 of the 4 GLT O-rings in two fixtures remaining leak-tight longer than the GLT-S O-ring fixtures. At $300{ }^{\circ} \mathrm{F}$, both GLT-S Oring fixtures remain leak-tight after 45 months, while 5 GLT O-ring fixtures had failed by this time. With this varying trend, it is premature to conclude one material would perform better than the other, especially at the lower temperatures typical of storage service. 


\section{Conclusions}

High temperature aging continues for 23 GLT O-ring fixtures at $200-270{ }^{\circ} \mathrm{F}$. Room temperature leak test failures have been experienced by one or both O-rings in 8 of the GLT Oring fixtures aging at $300{ }^{\circ} \mathrm{F}$, and in all 5 of the GLT O-ring fixtures aging at higher temperatures. The remaining $8 \mathrm{GLT}$ O-ring fixtures aging at $300 \mathrm{~F}$ were retired from testing following at least 61 months at temperature. No failures have yet been observed in GLT O-ring fixtures aging at $200{ }^{\circ} \mathrm{F}$ for 61 - 85 months, which is more representative of (but still bounding to) O-ring temperatures during storage in KAC. The maximum O-ring temperature possible in the $\mathrm{KAC}$ is $\sim 176^{\circ} \mathrm{F}$, based on a transient peak ambient temperature of $106^{\circ} \mathrm{F}$ and the maximum payload (19W). Average ambient temperatures and reduced payloads are less challenging to the seals in storage.

High temperature aging continues for 6 GLT-S O-ring fixtures at $200-300{ }^{\circ} \mathrm{F}$. Room temperature leak test failures have been experienced in all 8 of the GLT-S O-ring fixtures aging at 350 and $400{ }^{\circ} \mathrm{F}$. No failures have yet been observed in GLT-S O-ring fixtures aging at 200 $300{ }^{\circ} \mathrm{F}$ for 41 - 45 months.

Aging and periodic leak testing will continue for the remaining fixtures.

\section{References}

[1] WSRC-TR-2003-00325, Rev. 4, “Task Technical and Quality Assurance Plan for Characterization and Surveillance of Model 9975 Package O-Rings and Celotex ${ }^{\circledR}$ Materials (U)”, January 2009.

[2] SRNS-TR-2008-00054, Rev. 0, “Task Technical and Quality Assurance Plan for Accelerated Aging of Viton ${ }^{\circledR}$ GLT-S O-rings for Model 9975 Shipping Packages in KAMS (U)”, January 2009.

[3] WSRC-TR-2001-0286, Rev. 4, "SRS Surveillance Program for Storage of Pu Material in KAMS”, July 2008.

[4] SRNL-TR-2009-00186, "Fourth Interim Status Report: Model 9975 PCV O-Ring Fixture Long-Term Leak Performance”, W. L. Daugherty and T. M. Stefek, June 2009

[5] WSRC-SA-2002-00008, Rev. 0, “Safety Analysis Report for Packaging - Model 9975”, December 2003.

[6] ANSI Standard N14.5-97, “American National Standard for Radioactive Materials Leakage Tests on Packages for Shipment”, American National Standards Institute, New York, NY, February 1998.

[7] SRNL-L1400-2008-00038, “Characterization of Leak Test System for O-Ring Studies”, D. J. Trapp, December 18, 2008. 
[8] SRNL-TR-2012-00181, "Seventh Interim Status Report: Model 9975 PCV O-Ring Fixture Long-Term Leak Performance”, W. L. Daugherty, August 2012.

[9] SRNS-TR-2008-00290, Rev. 0, "Summary and Matrix 9975 Shipping Package Qualification Program for Extended Storage of Plutonium in the K Area Complex”, J. A. Radder, Savannah River Nuclear Solutions, Aiken, SC, November 2008.

[10] M-CLC-K-00729, Rev. 0, "Thermal Analysis of the 9975 Package with Softwood-Based Fiberboard during KAMS Facility Fire”, N. K. Gupta, June 11, 2008, and M-CLC-K-00727, Rev. 0, "Thermal Model Study for the 9975 Package in KAMS during Facility Fire”, N. K. Gupta and D. Tamburello, June 11, 2008.

[11] L9.4-10500, Rev. 2, “Annual Maintenance and Leak Testing for the 9975 Shipping Package,” Instrumentation and Equipment Systems Section, SRNL, August 29, 2007.

Table 1. Test Matrix Variables for O-Ring Experiment

\begin{tabular}{|c|c|c|}
\hline $\begin{array}{l}\text { Test } \\
\text { Variable }\end{array}$ & Values Tested & Basis for Values Tested \\
\hline \multirow[t]{3}{*}{ Temperature } & $\begin{array}{l}200^{\circ} \mathrm{F} \\
\left(93^{\circ} \mathrm{C}\right)\end{array}$ & $\begin{array}{l}\text { With loss of ventilation in the KAC facility, the } \\
\text { maximum ambient temperature is } 137{ }^{\circ} \mathrm{F} \text { [9], and the } \\
\text { corresponding PCV O-ring temperature is } 199^{\circ} \mathrm{F} \text { [10]. }\end{array}$ \\
\hline & $\begin{array}{l}300^{\circ} \mathrm{F} \\
\left(149^{\circ} \mathrm{C}\right)\end{array}$ & $\begin{array}{l}\text { The maximum allowable temperature for the PCV O- } \\
\text { rings for continuous operation is } 300^{\circ} \mathrm{F}[5] \text {. }\end{array}$ \\
\hline & $\begin{array}{l}270,350,400 \\
450^{\circ} \mathrm{F} \\
(132,177,204 \\
\left.232^{\circ} \mathrm{C}\right)\end{array}$ & $\begin{array}{l}\text { Elevated temperatures added to increase the likelihood } \\
\text { of seeing O-ring failures in shorter test periods. }\end{array}$ \\
\hline \multirow[t]{3}{*}{$\begin{array}{l}\text { Radiation } \\
\text { Dose }\end{array}$} & $\begin{array}{l}\text { 2E5 } \mathrm{Rad} \text { in } 72 \\
\text { min }\end{array}$ & $\begin{array}{l}\text { The bounding (high) dose rate for the PCV is } 2 \mathrm{rad} / \mathrm{hr} \text {. } \\
\text { A total dose of } 2 \mathrm{E} 5 \mathrm{rad} \text { represents ten years of storage } \\
\text { (the initial period to be validated). }\end{array}$ \\
\hline & $\begin{array}{l}\text { 2E5 Rad in } \\
>200 \mathrm{hr}\end{array}$ & $\begin{array}{l}\text { Longer-term exposure may reveal the added effect of } \\
\text { diffusion-limited oxidation (DLO) that only occurs with } \\
\text { long-term exposure. (lower dose rate) }\end{array}$ \\
\hline & None & $\begin{array}{l}\text { Many packages will have little radiation exposure. This } \\
\text { also serves as an experimental control. }\end{array}$ \\
\hline \multirow[t]{3}{*}{$\begin{array}{l}\text { O-Ring } \\
\text { Lubrication }\end{array}$} & $\begin{array}{l}\text { Silicone high- } \\
\text { vacuum grease }\end{array}$ & It is specified in assembly of the 9975 package [11]. \\
\hline & Krytox® 240AC & $\begin{array}{l}\text { It has been used on } 9975 \text { O-rings at DOE facilities. It is } \\
\text { used on lid components of the } 9975 \text { PCV and SCV [11]. }\end{array}$ \\
\hline & None & $\begin{array}{l}\text { It supplies comparative control data. Also, it is possible } \\
\text { that the O-rings may be mistakenly installed without } \\
\text { grease. }\end{array}$ \\
\hline
\end{tabular}


Table 2. Summary of test parameters for fixtures

\begin{tabular}{|c|c|c|c|c|c|c|}
\hline \multirow[b]{2}{*}{$\begin{array}{l}\text { Temp. } \\
{ }^{\circ} \mathbf{F}\end{array}$} & \multirow[b]{2}{*}{$\begin{array}{l}\text { Gamma } \\
\text { Dose (rad) / } \\
\text { Dose Rate }\end{array}$} & \multirow[b]{2}{*}{ Lubricant } & \multicolumn{4}{|c|}{\begin{tabular}{|l|l|} 
Fixtures Still in Fixtures Removed from Test \\
\end{tabular}} \\
\hline & & & Test & $\begin{array}{l}\text { Failed Leak } \\
\text { Test at } \\
\text { Room Temp } \\
\end{array}$ & $\begin{array}{l}\text { Retired } \\
\text { July } \\
2012 \\
\end{array}$ & $\begin{array}{l}\text { For Other } \\
\text { Reasons }\end{array}$ \\
\hline \multicolumn{7}{|c|}{ GLT O-ring Fixtures - First Test Matrix } \\
\hline 200 & 2E5 High & Normal & $\begin{array}{l}5,6,9,27,36, \\
37,40,41,42, \\
53,54,55\end{array}$ & & & $15,16,23,24$ \\
\hline 200 & $\sim 2 \mathrm{E} 5 \mathrm{Low}$ & Normal & 10,11 & & & \\
\hline 200 & No & Normal & $\begin{array}{l}1,3, \quad 43,44 \\
56,57\end{array}$ & & & $13,28,29$ \\
\hline 300 & 2E5 High & Normal & & $8,12,26,31$ & $7,51,52$ & $\begin{array}{l}17,22,25,39, \\
45,46,47,58, \\
59,60\end{array}$ \\
\hline 300 & $\sim 2 \mathrm{E} 5$ Low & Normal & & 32 & $18,30^{*}$ & 21,38 \\
\hline 300 & No & Normal & & 49, 33 & 4,61 & $\begin{array}{l}2,14,48,50, \\
62\end{array}$ \\
\hline 300 & 2E5 High & None & & & & 19 \\
\hline 300 & No & None & & & & 34 \\
\hline 200 & No & Krytox & 35 & & & \\
\hline 300 & $\sim 2 \mathrm{E} 5 \mathrm{Low}$ & Krytox & & & 20 & \\
\hline \multicolumn{7}{|c|}{ GLT O-ring Fixtures - Second Test Matrix } \\
\hline 270 & No & Normal & $14 \mathrm{~W}$ & & & \\
\hline 270 & No & Normal & $21 \mathrm{~W}$ & & & \\
\hline 350 & 2E5 High & Normal & & $18 \mathrm{D}$ & & \\
\hline 350 & No & Normal & & 19D & & \\
\hline 400 & 2E5 High & Normal & & 14D & & \\
\hline 400 & No & Normal & & $21 \mathrm{D}$ & & \\
\hline 450 & 2E5 High & Normal & & $23 \mathrm{D}$ & & \\
\hline \multicolumn{7}{|c|}{ GLT-S O-ring Fixtures - Third Test Matrix } \\
\hline 200 & None & Normal & $13 \mathrm{H}, 15 \mathrm{H}$ & & & \\
\hline 250 & None & Normal & $22 \mathrm{H}, 16 \mathrm{H}$ & & & \\
\hline 300 & None & Normal & $29 \mathrm{H}, 34 \mathrm{H}$ & & & \\
\hline 350 & None & Normal & & $38 \mathrm{H}, 39 \mathrm{H}$ & & \\
\hline 400 & None & Normal & & $45 \mathrm{H}, 58 \mathrm{H}$ & & \\
\hline 400 & None & Normal & & $60 \mathrm{H}, 62 \mathrm{H}$ & & \\
\hline 400 & 2E5 High & Normal & & $28 \mathrm{H}, 50 \mathrm{H}$ & & \\
\hline
\end{tabular}

* Fixture 30 has 1 failed O-ring (inner). 
Table 3. Summary of GLT and GLT-S O-ring leak failures

\begin{tabular}{|c|c|c|c|}
\hline & & \multicolumn{2}{|c|}{ Days at temperature to failure * } \\
\hline Fixture & $\begin{array}{c}\text { Temp } \\
\left({ }^{\circ} \mathrm{F}\right)\end{array}$ & Inner & Outer \\
\hline \multicolumn{4}{|c|}{ GLT O-ring Fixtures } \\
\hline 8 & 300 & $2009-2082$ & $2009-2082$ \\
\hline 12 & 300 & $957-1020$ & $957-1020$ \\
\hline 26 & 300 & $1273-1366$ & $1261-1273$ \\
\hline 30 & 300 & $1279-1392$ & 1902 - no fail \\
\hline 31 & 300 & $1280-1291$ & $1280-1291$ \\
\hline 32 & 300 & $1271-1352$ & $1271-1352$ \\
\hline 33 & 300 & $1360-1466$ & $1924-1979$ \\
\hline 49 & 300 & $1101-1276$ & $1323-1360$ \\
\hline 18D & 350 & $481-497$ & $304-324$ \\
\hline 19D & 350 & $573-594$ & $560-571$ \\
\hline 14D & 400 & $29-45$ & $29-45$ \\
\hline $21 \mathrm{D}$ & 400 & $8-28$ & $8-28$ \\
\hline 23D & 450 & $10-12$ & $0-8$ \\
\hline \multicolumn{4}{|c|}{ GLT-S O-ring Fixtures } \\
\hline $38 \mathrm{H}$ & 350 & $338-358$ & $338-358$ \\
\hline $39 \mathrm{H}$ & 350 & $95-114$ & $95-114$ \\
\hline $45 \mathrm{H}$ & 400 & $65-99$ & $14-33$ \\
\hline $58 \mathrm{H}$ & 400 & $62-75$ & $62-75$ \\
\hline $60 \mathrm{H}$ & 400 & $33-50$ & $33-50$ \\
\hline $62 \mathrm{H}$ & 400 & $34-50$ & $34-50$ \\
\hline $28 \mathrm{H}$ & 400 & $33-50$ & $33-50$ \\
\hline $50 \mathrm{H}$ & 400 & $260-281$ & $260-281$ \\
\hline
\end{tabular}

* The first time at temperature is the last successful leak test. The second time at temperature is the failed leak test. Failure occurred at some point between these two times. 
Table 4. Room temperature leak rate data since 2011 (for fixtures in test since last status report)

\begin{tabular}{|l|l|l|}
\hline \multicolumn{2}{|l|}{ Test $1,200^{\circ} \mathrm{F}$} \\
\hline No rad. & $\begin{array}{l}\text { Time at Temp } \\
\text { (months) }\end{array}$ & $\begin{array}{l}\text { Leak Rate (std } \\
\text { cc He/sec) }\end{array}$ \\
\hline Date & 60 & $<3.0$ E-8 \\
\hline $3 / 15 / 2011$ & 60 & $<3.0$ E-8 \\
\hline $9 / 19 / 2011$ & 66 & $<2.0$ E-9 \\
\hline $3 / 19 / 2012$ & 72 & 1.3 E-8 \\
\hline $10 / 8 / 2012$ & 78 & 5.3 E-9 \\
\hline $7 / 9 / 2013$ & 85 &
\end{tabular}

\begin{tabular}{|l|l|l|}
\hline \multicolumn{3}{|l|}{ Test 3, $200^{\circ} \mathrm{F}$} \\
\hline No rad. & $\begin{array}{l}\text { Time at Temp } \\
\text { (months) }\end{array}$ & $\begin{array}{l}\text { Leak Rate (std } \\
\text { cc He/sec) }\end{array}$ \\
\hline Date & 59 & $<2.8$ E-8 \\
\hline $2 / 1 / 2011$ & 65 & $<1.8$ E-8 \\
\hline $8 / 1 / 2011$ & 72 & $<1.6$ E-8 \\
\hline $2 / 22 / 2012$ & 72 & $<1.0$ E-8 \\
\hline $9 / 5 / 2012$ & 80 & 5.9 E-9 \\
\hline $5 / 14 / 2013$ & 84 &
\end{tabular}

\begin{tabular}{|l|l|l|}
\hline \multicolumn{3}{|l|}{ Test $5, \quad 200^{\circ} \mathrm{F}$} \\
\hline 2E5Rad $/ 72$ min \\
\hline Date & $\begin{array}{l}\text { Time at Temp } \\
\text { (months) }\end{array}$ & $\begin{array}{l}\text { Leak Rate (std } \\
\text { cc He/sec) }\end{array}$ \\
\hline $3 / 14 / 2011$ & 59 & $<2.4$ E-8 \\
\hline $10 / 24 / 2011$ & 66 & $<2.6$ E-8 \\
\hline $4 / 30 / 2012$ & 71 & 1.0 E-7 \\
\hline $11 / 15 / 2012$ & 78 & $<1.6$ E-9 \\
\hline & & \\
\hline
\end{tabular}

\begin{tabular}{|l|l|l|}
\hline \multicolumn{3}{|l|}{ Test 6, $200^{\circ} \mathrm{F}$} \\
\hline 2E5Rad $/ 72$ min \\
\hline Date & $\begin{array}{l}\text { Time at Temp } \\
(\text { months) }\end{array}$ & $\begin{array}{l}\text { Leak Rate (std } \\
\text { cc He/sec) }\end{array}$ \\
\hline $3 / 14 / 2011$ & 59 & $<2.0$ E-8 \\
\hline $10 / 24 / 2011$ & 66 & $<2.8$ E-8 \\
\hline $5 / 1 / 2012$ & 72 & $<3.4$ E-8 \\
\hline $11 / 15 / 2012$ & 78 & 9.1 E-9 \\
\hline $7 / 9 / 2013$ & 84 & 1.5 E-8 \\
\hline
\end{tabular}

\begin{tabular}{|l|l|l|}
\hline \multicolumn{3}{|l|}{ Test 9, $200{ }^{\circ} \mathrm{F}$} \\
\hline 2E5Rad $/ 72$ min \\
\hline Date & $\begin{array}{l}\text { Time at Temp } \\
\text { (months) }\end{array}$ & $\begin{array}{l}\text { Leak Rate (std } \\
\text { cc He/sec) }\end{array}$ \\
\hline $6 / 27 / 2011$ & 53 & $2.6 \mathrm{E}-8$ \\
\hline $1 / 24 / 2012$ & 59 & $2.4 \mathrm{E}-9$ \\
\hline $8 / 15 / 2012$ & 66 & $<1.2 \mathrm{E}-8$ \\
\hline $4 / 9 / 2013$ & 72 & $<2.4 \mathrm{E}-9$ \\
\hline & & \\
\hline
\end{tabular}

\begin{tabular}{|l|l|l|}
\hline \multicolumn{3}{|l|}{ Test 10, $200{ }^{\circ} \mathrm{F}$} \\
\hline 2E5Rad $/ 240 \mathrm{hr}$ \\
\hline Date & $\begin{array}{l}\text { Time at Temp } \\
(\mathrm{months})\end{array}$ & $\begin{array}{l}\text { Leak Rate (std } \\
\text { cc He/sec) }\end{array}$ \\
\hline $2 / 15 / 2011$ & 54 & $<2.2 \mathrm{E}-8$ \\
\hline $8 / 16 / 2011$ & 60 & $<4.0 \mathrm{E}-9$ \\
\hline $2 / 22 / 2012$ & 66 & $<2.0 \mathrm{E}-8$ \\
\hline $9 / 10 / 2012$ & 72 & $1.6 \mathrm{E}-8$ \\
\hline $5 / 14 / 2013$ & 78 & $<1.7 \mathrm{E}-9$ \\
\hline
\end{tabular}

\begin{tabular}{|l|l|l|}
\hline \multicolumn{3}{|l|}{ Test 11, $200^{\circ} \mathrm{F}$} \\
\hline 1.4E5 Rad $/ 479 \mathrm{hr}$ \\
\hline Date & $\begin{array}{l}\text { Time at Temp } \\
\text { (months) }\end{array}$ & $\begin{array}{l}\text { Leak Rate (std } \\
\text { cc He/sec) }\end{array}$ \\
\hline $2 / 15 / 2011$ & 54 & $<2.6 \mathrm{E}-8$ \\
\hline $8 / 16 / 2011$ & 59 & $2.7 \mathrm{E}-7 *$ \\
\hline $3 / 19 / 2012$ & 66 & $<2.4 \mathrm{E}-8$ \\
\hline $10 / 8 / 2012$ & 72 & $2.7 \mathrm{E}-9$ \\
\hline $6 / 4 / 2013$ & 78 & $5.5 \mathrm{E}-9$ \\
\hline
\end{tabular}

\begin{tabular}{|l|l|l|}
\hline \multicolumn{3}{|l|}{ Test 27, $200{ }^{\circ} \mathrm{F}$} \\
\hline 2E5Rad $/ 72$ min \\
\hline Date & $\begin{array}{l}\text { Time at Temp } \\
\text { (months) }\end{array}$ & $\begin{array}{l}\text { Leak Rate (std } \\
\text { cc He/sec) }\end{array}$ \\
\hline $3 / 15 / 2011$ & 41 & $<1.6$ E-8 \\
\hline $10 / 24 / 2011$ & 48 & $<2.6$ E-8 \\
\hline $5 / 30 / 2012$ & 54 & $<2.8$ E-8 \\
\hline $12 / 11 / 2012$ & 61 & 5.8 E-9 \\
\hline & & \\
\hline
\end{tabular}

* Test 11 - failed bag test at 59 months. Each O-ring ok individually. 
Table 4. (cont) Room temperature leak rate data since 2011 (for fixtures in test since last status report)

\begin{tabular}{|l|l|l|}
\hline \multicolumn{2}{|l|}{ Test 35, $200{ }^{\circ} \mathrm{F}$} \\
\hline No rad. & $\begin{array}{l}\text { Time at Temp } \\
\text { (months) }\end{array}$ & $\begin{array}{l}\text { Leak Rate (std } \\
\text { cc He/sec) }\end{array}$ \\
\hline $3 / 15 / 2011$ & 54 & $<1.8 \mathrm{E}-8$ \\
\hline $10 / 24 / 2011$ & 60 & $<2.6 \mathrm{E}-8$ \\
\hline $4 / 30 / 2012$ & 66 & $<2.6 \mathrm{E}-8$ \\
\hline $11 / 15 / 2012$ & 73 & $<1.6 \mathrm{E}-9$ \\
\hline $7 / 9 / 2013$ & 78 & $1.7 \mathrm{E}-8$ \\
\hline
\end{tabular}

\begin{tabular}{|l|l|l|}
\hline \multicolumn{3}{|l|}{ Test 36, $200{ }^{\circ} \mathrm{F}$} \\
\hline 2E5Rad $/ 72$ min \\
\hline Date & $\begin{array}{l}\text { Time at Temp } \\
\text { (months) }\end{array}$ & $\begin{array}{l}\text { Leak Rate (std } \\
\text { cc He/sec) }\end{array}$ \\
\hline $2 / 15 / 2011$ & 53 & $<3.2 \mathrm{E}-8$ \\
\hline $8 / 16 / 2011$ & 60 & $<6.0 \mathrm{E}-9$ \\
\hline $3 / 19 / 2012$ & 66 & $<2.2 \mathrm{E}-8$ \\
\hline $10 / 8 / 2012$ & 72 & $<1.9 \mathrm{E}-9$ \\
\hline $6 / 4 / 2013$ & 78 & $<1.9 \mathrm{E}-9$ \\
\hline
\end{tabular}

\begin{tabular}{|l|l|l|}
\hline \multicolumn{3}{|l|}{ Test 37, $200^{\circ} \mathrm{F}$} \\
\hline 2E5Rad $/ 72$ min \\
\hline Date & $\begin{array}{l}\text { Time at Temp } \\
\text { (months) }\end{array}$ & $\begin{array}{l}\text { Leak Rate (std } \\
\text { cc He/sec) }\end{array}$ \\
\hline $2 / 15 / 2011$ & 53 & $<3.6$ E-8 \\
\hline $8 / 16 / 2011$ & 60 & $<6.0$ E-9 \\
\hline $3 / 19 / 2012$ & 66 & $<2.0$ E-8 \\
\hline $10 / 8 / 2012$ & 72 & 2.7 E-8 \\
\hline $6 / 4 / 2013$ & 78 & $<1.9$ E-9 \\
\hline
\end{tabular}

\begin{tabular}{|l|l|l|}
\hline \multicolumn{3}{|l|}{ Test 40, $200^{\circ} \mathrm{F}$} \\
\hline 2E5Rad $/ 72 \mathrm{~min}$ \\
\hline Date & $\begin{array}{l}\text { Time at Temp } \\
\text { (months) }\end{array}$ & $\begin{array}{l}\text { Leak Rate (std } \\
\text { cc He/sec) }\end{array}$ \\
\hline $6 / 27 / 2011$ & 53 & $<1.2 \mathrm{E}-8$ \\
\hline $1 / 24 / 2012$ & 60 & $<3.4 \mathrm{E}-8$ \\
\hline $8 / 15 / 2012$ & 66 & $<1.4 \mathrm{E}-8$ \\
\hline $4 / 9 / 2013$ & 72 & $2.2 \mathrm{E}-9$ \\
\hline & & \\
\hline
\end{tabular}

\begin{tabular}{|l|l|l|}
\hline \multicolumn{3}{|l|}{ Test 41, $200{ }^{\circ} \mathrm{F}$} \\
\hline 2E5Rad $/ 72$ min \\
\hline Date & $\begin{array}{l}\text { Time at Temp } \\
\text { (months) }\end{array}$ & $\begin{array}{l}\text { Leak Rate (std } \\
\text { cc He/sec) }\end{array}$ \\
\hline $2 / 1 / 2011$ & 53 & $<3.4$ E-8 \\
\hline $8 / 1 / 2011$ & 59 & $<1.4$ E-8 \\
\hline $2 / 22 / 2012$ & 65 & $<2.6$ E-8 \\
\hline $9 / 10 / 2012$ & 72 & $<1.6$ E-8 \\
\hline $5 / 14 / 2013$ & 78 & $<1.7$ E-9 \\
\hline
\end{tabular}

\begin{tabular}{|l|l|l|}
\hline \multicolumn{3}{|l|}{ Test 42, $200{ }^{\circ} \mathrm{F}$} \\
\hline 2E5Rad $/ 72 \mathrm{~min}$ \\
\hline Date & $\begin{array}{l}\text { Time at Temp } \\
\text { (months) }\end{array}$ & $\begin{array}{l}\text { Leak Rate (std } \\
\text { cc He/sec) }\end{array}$ \\
\hline $2 / 1 / 2011$ & 53 & $<2.8 \mathrm{E}-8$ \\
\hline $8 / 1 / 2011$ & 60 & $<1.2 \mathrm{E}-8$ \\
\hline $2 / 22 / 2012$ & 65 & $<1.6 \mathrm{E}-8$ \\
\hline $9 / 6 / 2012$ & 72 & $<1.2 \mathrm{E}-8$ \\
\hline $5 / 14 / 2013$ & 78 & $7.1 \mathrm{E}-9$ \\
\hline
\end{tabular}

\begin{tabular}{|l|l|l|}
\hline \multicolumn{2}{|l|}{ Test 43, $200{ }^{\circ} \mathrm{F}$} \\
\hline No rad. & $\begin{array}{l}\text { Time at Temp } \\
\text { (months) }\end{array}$ & $\begin{array}{l}\text { Leak Rate (std } \\
\text { cc He/sec) }\end{array}$ \\
\hline Date & 53 & $<3.6$ E-8 \\
\hline $2 / 15 / 2011$ & 59 & $<4.0$ E-9 \\
\hline $8 / 16 / 2011$ & 59 & $<9.8$ E-10 \\
\hline $3 / 19 / 2012$ & 66 & 2.7 E-9 \\
\hline $10 / 8 / 2012$ & 72 & $<1.9$ E-9 \\
\hline $6 / 4 / 2013$ & 78 &
\end{tabular}

\begin{tabular}{|l|l|l|}
\hline \multicolumn{3}{|l|}{ Test 44, $200^{\circ} \mathrm{F}$} \\
\hline No rad. \\
\hline Date & $\begin{array}{l}\text { Time at Temp } \\
\text { (months) }\end{array}$ & $\begin{array}{l}\text { Leak Rate (std } \\
\text { cc He/sec) }\end{array}$ \\
\hline $2 / 1 / 2011$ & 54 & $<2.4 \mathrm{E}-8$ \\
\hline $8 / 1 / 2011$ & 60 & $<1.4 \mathrm{E}-8$ \\
\hline $2 / 22 / 2012$ & 66 & $<2.0 \mathrm{E}-8$ \\
\hline $9 / 6 / 2012$ & 72 & $<1.0 \mathrm{E}-8$ \\
\hline $5 / 14 / 2013$ & 78 & $<1.7 \mathrm{E}-9$ \\
\hline
\end{tabular}


Table 4. (cont) Room temperature leak rate data since 2011 (for fixtures in test since last status report)

\begin{tabular}{|l|l|l|}
\hline \multicolumn{2}{|l|}{ Test 53, $200{ }^{\circ} \mathrm{F}$} \\
\hline 2E5Rad $/ 72 \mathrm{~min}$ \\
\hline Date & $\begin{array}{l}\text { Time at Temp } \\
\text { (months) }\end{array}$ & $\begin{array}{l}\text { Leak Rate }(\text { std } \\
\text { cc He/sec) }\end{array}$ \\
\hline $2 / 1 / 2011$ & 54 & $<3.2 \mathrm{E}-8$ \\
\hline $8 / 1 / 2011$ & 60 & $<3.6 \mathrm{E}-8$ \\
\hline $2 / 22 / 2012$ & 66 & $<2.0 \mathrm{E}-8$ \\
\hline $9 / 10 / 2012$ & 72 & $<2.2 \mathrm{E}-8$ \\
\hline $5 / 14 / 2013$ & 78 & $1.2 \mathrm{E}-8$ \\
\hline
\end{tabular}

\begin{tabular}{|l|l|l|}
\hline \multicolumn{3}{|l|}{ Test 54, $200{ }^{\circ} \mathrm{F}$} \\
\hline 2E5Rad $/ 72$ min \\
\hline Date & $\begin{array}{l}\text { Time at Temp } \\
\text { (months) }\end{array}$ & $\begin{array}{l}\text { Leak Rate (std } \\
\text { cc He/sec) }\end{array}$ \\
\hline $2 / 1 / 2011$ & 54 & $<1.8 \mathrm{E}-8$ \\
\hline $8 / 1 / 2011$ & 59 & $<2.6 \mathrm{E}-8$ \\
\hline $2 / 22 / 2012$ & 66 & $<1.9 \mathrm{E}-8$ \\
\hline $9 / 10 / 2012$ & 72 & $<2.0 \mathrm{E}-8$ \\
\hline $5 / 14 / 2013$ & 78 & $1.2 \mathrm{E}-8$ \\
\hline
\end{tabular}

\begin{tabular}{|l|l|l|}
\hline \multicolumn{3}{|l|}{ Test $55, \quad 200^{\circ} \mathrm{F}$} \\
\hline 2E5Rad $/ 72$ min \\
\hline Date & $\begin{array}{l}\text { Time at Temp } \\
\text { (months) }\end{array}$ & $\begin{array}{l}\text { Leak Rate }(\text { std } \\
\text { cc He/sec) }\end{array}$ \\
\hline $2 / 1 / 2011$ & 53 & $<3.0$ E-8 \\
\hline $8 / 1 / 2011$ & 59 & $<1.0$ E-8 \\
\hline $2 / 22 / 2012$ & 65 & $<1.6$ E-8 \\
\hline $9 / 10 / 2012$ & 72 & $<1.6$ E-8 \\
\hline $5 / 14 / 2013$ & 78 & 2.4 E-9 \\
\hline
\end{tabular}

\begin{tabular}{|l|l|l|}
\hline \multicolumn{3}{|l|}{ Test 56, $200{ }^{\circ} \mathrm{F}$} \\
\hline No rad. \\
\hline Date & $\begin{array}{l}\text { Time at Temp } \\
\text { (months) }\end{array}$ & $\begin{array}{l}\text { Leak Rate (std } \\
\text { cc He/sec) }\end{array}$ \\
\hline $3 / 15 / 2011$ & 53 & $<2.2 \mathrm{E}-8$ \\
\hline $10 / 24 / 2011$ & 60 & $<3.2 \mathrm{E}-8$ \\
\hline $4 / 30 / 2012$ & 66 & $<1.8 \mathrm{E}-8$ \\
\hline $11 / 15 / 2012$ & 72 & $<1.6 \mathrm{E}-9$ \\
\hline $7 / 9 / 2013$ & 78 & $1.1 \mathrm{E}-8$ \\
\hline
\end{tabular}

\begin{tabular}{|l|l|l|}
\hline \multicolumn{3}{|l|}{ Test 57, $200^{\circ} \mathrm{F}$} \\
\hline No rad. \\
\hline Date & $\begin{array}{l}\text { Time at Temp } \\
\text { (months) }\end{array}$ & $\begin{array}{l}\text { Leak Rate (std } \\
\text { cc He/sec) }\end{array}$ \\
\hline $2 / 15 / 2011$ & 53 & $<2.6$ E-8 \\
\hline $8 / 16 / 2011$ & 59 & $<6.0$ E-9 \\
\hline $3 / 20 / 2012$ & 66 & $<1.8$ E-8 \\
\hline $10 / 8 / 2012$ & 72 & $<1.9$ E-9 \\
\hline $6 / 4 / 2013$ & 78 & 2.8 E-9 \\
\hline
\end{tabular}

\begin{tabular}{|l|l|l|}
\hline \multicolumn{3}{|l|}{ Test 14W, $270^{\circ} \mathrm{F}$} \\
\hline No rad. & $\begin{array}{l}\text { Time at Temp } \\
\text { (months) }\end{array}$ & $\begin{array}{l}\text { Leak Rate (std } \\
\text { cc He/sec) }\end{array}$ \\
\hline Date & Baseline & $<1.6$ E-8 \\
\hline $4 / 18 / 2011$ & 5 & $<2.6$ E-8 \\
\hline $10 / 24 / 2011$ & 5 & $<2.8$ E-8 \\
\hline $5 / 30 / 2012$ & 12 & \\
\hline & & \\
\hline & & \\
\hline
\end{tabular}

\begin{tabular}{|l|l|l|}
\hline \multicolumn{2}{|l|}{ Test 21W, $270^{\circ} \mathrm{F}$} \\
\hline No rad. & $\begin{array}{l}\text { Time at Temp } \\
\text { (months) }\end{array}$ & $\begin{array}{l}\text { Leak Rate (std } \\
\text { cc He/sec) }\end{array}$ \\
\hline Date & Baseline & $<1.6$ E-8 \\
\hline $4 / 18 / 2011$ & $<2.4$ E-8 \\
\hline $10 / 24 / 2011$ & 6 & $<3.0$ E-8 \\
\hline $5 / 30 / 2012$ & 12 & \\
\hline & & \\
\hline & & \\
\hline
\end{tabular}


Table 4. (cont) Room temperature leak rate data since 2011 (for fixtures in test since last status report)

\begin{tabular}{|l|l|l|}
\hline \multicolumn{2}{|l|}{ Test 13H (GLT-S), $200^{\circ} \mathrm{F}$} \\
\hline No rad. & $\begin{array}{l}\text { Time at Temp } \\
\text { (months) }\end{array}$ & $\begin{array}{l}\text { Leak Rate (std } \\
\text { cc He/sec) }\end{array}$ \\
\hline Date & 25 & $<1.6$ E-8 \\
\hline $6 / 27 / 2011$ & 3011 & $<1.8$ E-8 \\
\hline $11 / 28 / 2011$ & 30 & $<3.8$ E-8 \\
\hline $5 / 29 / 2012$ & 35 & 5.8 E-9 \\
\hline $12 / 11 / 2012$ & 42 & \\
\hline & &
\end{tabular}

\begin{tabular}{|l|l|l|}
\hline \multicolumn{3}{|l|}{ Test 15H (GLT-S), $200^{\circ} \mathrm{F}$} \\
\hline No rad. & $\begin{array}{l}\text { Time at Temp } \\
\text { (months) }\end{array}$ & $\begin{array}{l}\text { Leak Rate (std } \\
\text { cc He/sec) }\end{array}$ \\
\hline Date & 26 & $<1.0$ E-8 \\
\hline $6 / 27 / 2011$ & 30 & $<1.6$ E-8 \\
\hline $11 / 28 / 2011$ & 36 & $<4.2$ E-8 \\
\hline $5 / 29 / 2012$ & 36 & 5.8 E-9 \\
\hline $12 / 11 / 2012$ & 42 & \\
\hline & &
\end{tabular}

\begin{tabular}{|l|l|l|}
\hline \multicolumn{3}{|l|}{ Test $16 \mathrm{H}$ (GLT-S), $250^{\circ} \mathrm{F}$} \\
\hline No rad.. \\
\hline Date & $\begin{array}{l}\text { Time at Temp } \\
\text { (months) }\end{array}$ & $\begin{array}{l}\text { Leak Rate (std } \\
\text { cc He/sec) }\end{array}$ \\
\hline $6 / 27 / 2011$ & 22 & $<1.8$ E-8 \\
\hline $3 / 20 / 2012$ & 30 & 1.6 E-8 \\
\hline $10 / 8 / 2012$ & 36 & 1.3 E-8 \\
\hline $6 / 4 / 2013$ & 41 & $<1.9$ E-9 \\
\hline & & \\
\hline
\end{tabular}

\begin{tabular}{|l|l|l|}
\hline \multicolumn{3}{|l|}{ Test 22H (GLT-S), $250^{\circ} \mathrm{F}$} \\
\hline No rad. & $\begin{array}{l}\text { Time at Temp } \\
\text { (months) }\end{array}$ & $\begin{array}{l}\text { Leak Rate (std } \\
\text { cc He/sec) }\end{array}$ \\
\hline Date & 24 & $<1.4 \mathrm{E}-8$ \\
\hline $6 / 27 / 2011$ & 30 & $<2.6 \mathrm{E}-8$ \\
\hline $1 / 24 / 2012$ & 37 & $<1.1 \mathrm{E}-8$ \\
\hline $8 / 15 / 2012$ & 37 & $5.4 \mathrm{E}-8$ \\
\hline $4 / 9 / 2013$ & 42 & \\
\hline & &
\end{tabular}

\begin{tabular}{|l|l|l|}
\hline \multicolumn{3}{|l|}{ Test 29H (GLT-S), $300^{\circ} \mathrm{F}$} \\
\hline No rad. \\
\hline Date & $\begin{array}{l}\text { Time at Temp } \\
\text { (months) }\end{array}$ & $\begin{array}{l}\text { Leak Rate } \text { (std } \\
\text { cc He/sec) }\end{array}$ \\
\hline $3 / 15 / 2011$ & 20 & $<2.6$ E-8 \\
\hline $6 / 8 / 2011$ & 23 & $<2.4$ E-8 \\
\hline $10 / 18 / 2011$ & 27 & 3.9 E-8 \\
\hline $1 / 10 / 2012$ & 30 & $<2.8$ E-8 \\
\hline $4 / 30 / 2012$ & 33 & 3.4 E-8 \\
\hline $8 / 15 / 2012$ & 36 & $<1.1$ E-8 \\
\hline $11 / 15 / 2012$ & 39 & 9.1 E-9 \\
\hline $4 / 9 / 2013$ & 42 & 9.9 E-9 \\
\hline $7 / 9 / 2013$ & 45 & 1.3 E-8 \\
\hline
\end{tabular}

\begin{tabular}{|l|l|l|}
\hline \multicolumn{3}{|l|}{ Test 34H (GLT-S), $300{ }^{\circ} \mathrm{F}$} \\
\hline No rad. \\
\hline Date & $\begin{array}{l}\text { Time at Temp } \\
\text { (months) }\end{array}$ & $\begin{array}{l}\text { Leak Rate (std } \\
\text { cc He/sec) }\end{array}$ \\
\hline $3 / 15 / 2011$ & 21 & $<1.7$ E-8 \\
\hline $6 / 8 / 2011$ & 24 & $<1.4$ E-8 \\
\hline $9 / 19 / 2011$ & 27 & $<3.2$ E-8 \\
\hline $12 / 28 / 2011$ & 30 & $<3.0$ E-8 \\
\hline $3 / 19 / 2012$ & 33 & $<2.2$ E-8 \\
\hline $7 / 11 / 2012$ & 36 & $<1.4$ E-8 \\
\hline $10 / 8 / 2012$ & 39 & 8.0 E-9 \\
\hline $3 / 5 / 2013$ & 42 & 2.3 E-9 \\
\hline $6 / 4 / 2013$ & 45 & 5.5 E-9 \\
\hline
\end{tabular}


Table 5. Summary of compression set data* from O-ring fixtures

\begin{tabular}{|c|c|c|c|c|c|c|}
\hline Fixture ID \& History & $\begin{array}{l}\text { Time since } \\
\text { Opening }\end{array}$ & $\begin{array}{ll}\text { Comp. Set - } \\
\text { Inner / Outer } \\
\text { O-ring }\end{array}$ & $\begin{array}{l}\text { Time since } \\
\text { Opening }\end{array}$ & $\begin{array}{l}\text { Comp. Set - } \\
\text { Inner / Outer } \\
\text { O-ring }\end{array}$ & $\begin{array}{l}\text { Time } \\
\text { since } \\
\text { Opening }\end{array}$ & $\begin{array}{l}\text { Comp. Set - } \\
\text { Inner / Outer } \\
\text { O-ring }\end{array}$ \\
\hline \multicolumn{7}{|c|}{ GLT O-Ring Fixtures reported previously with high temperature leak test difficulties } \\
\hline 2 (392 days at $300^{\circ} \mathrm{F}$ ) & & & & & 30 days & $62 \% / 59 \%$ \\
\hline 29 (283 days at $\left.200^{\circ} \mathrm{F}\right)$ & & & & & 30 days & $30 \% / 18 \%$ \\
\hline 38 (473 days at $\left.300^{\circ} \mathrm{F}\right)$ & $<30 \mathrm{~min}$. & $85 \% / 87 \%$ & & & & \\
\hline 39 (456 days at $300^{\circ} \mathrm{F}$ ) & $<30 \min$. & $77 \% / 81 \%$ & & & & \\
\hline 45 (291 days at $300^{\circ} \mathrm{F}$ ) & & & & & 30 days & $60 \% / 71 \%$ \\
\hline 46 (493 days at $300^{\circ} \mathrm{F}$ ) & $<30 \mathrm{~min}$. & $76 \% / 75 \%$ & & & & \\
\hline 47 (394 days at $300^{\circ} \mathrm{F}$ ) & 1 hour & $80 \% / 81 \%$ & 5 days & $77 \% / 73 \%$ & 34 days & $68 \% / 72 \%$ \\
\hline $48\left(490\right.$ days at $\left.300^{\circ} \mathrm{F}\right)$ & $<30$ min. & $84 \% / 84 \%$ & & & & \\
\hline 50 (265 days at $300^{\circ} \mathrm{F}$ ) & & & & & 30 days & $42 \% / 38 \%$ \\
\hline 60 (454 days at $300^{\circ} \mathrm{F}$ ) & $<30 \mathrm{~min}$. & $88 \%$ / 89\% & & & & \\
\hline 62 (282 days at $\left.300^{\circ} \mathrm{F}\right)$ & & & & & 30 days & $50 \% / 54 \%$ \\
\hline \multicolumn{7}{|c|}{ GLT O-Ring Fixtures removed after failing room temperature leak test } \\
\hline 8 (2082 days at $\left.300^{\circ} \mathrm{F}\right)$ & 15 minutes & $90 \% / 92 \%$ & 13 days & $94 \% / 91 \%$ & 30 days & $94 \% / 89 \%$ \\
\hline 12 (1020 days at $\left.300^{\circ} \mathrm{F}\right)$ & 7 minutes & $82 \% / 70 \%$ & 14 days & $75 \% / 55 \%$ & 30 days & $74 \% / 49 \%$ \\
\hline 14D (45 days at $400^{\circ} \mathrm{F}$ ) & 21 minutes & $51 \% / 77 \%$ & 9 days & $54 \% / 74 \%$ & 85 days & $45 \% / 66 \%$ \\
\hline 18D (497 days at $\left.350^{\circ} \mathrm{F}\right)$ & 23 minutes & $91 \% / 96 \%$ & 14 days & $93 \% / 97 \%$ & 30 days & $92 \% / 97 \%$ \\
\hline 19D (594 days at $\left.350^{\circ} \mathrm{F}\right)$ & 13 minutes & $95 \% / 94 \%$ & 14 days & $98 \% / 98 \%$ & 30 days & $97 \%$ / 97\% \\
\hline 21D (27 days at $400^{\circ} \mathrm{F}$ ) & 27 minutes & $66 \% / 77 \%$ & 9 days & $58 \% / 69 \%$ & 80 days & $53 \% / 66 \%$ \\
\hline 23D (12 days at $450^{\circ} \mathrm{F}$ ) & 21 minutes & $65 \% / 70 \%$ & 14 days & $53 \% / 63 \%$ & 90 days & $54 \% / 59 \%$ \\
\hline $26\left(1410\right.$ days at $\left.300^{\circ} \mathrm{F}\right)$ & 10 minutes & $90 \% / 91 \%$ & 14 days & $88 \%$ / 89\% & 30 days & $88 \%$ / 88\% \\
\hline 31 (1292 days at $\left.300{ }^{\circ} \mathrm{F}\right)$ & 15 minutes & $84 \%$ / 78\% & 14 days & $80 \%$ / 67\% & 31 days & $78 \%$ / 65\% \\
\hline 32 (1352 days at $\left.300^{\circ} \mathrm{F}\right)$ & 14 minutes & $93 \% / 83 \%$ & 14 days & $90 \% / 73 \%$ & 31 days & $89 \% / 71 \%$ \\
\hline $49\left(1360\right.$ days at $\left.300^{\circ} \mathrm{F}\right)$ & 14 minutes & $84 \% / 81 \%$ & 14 days & $82 \% / 80 \%$ & 30 days & $81 \% / 79 \%$ \\
\hline $33\left(1979\right.$ days at $\left.300^{\circ} \mathrm{F}\right)$ & 10 minutes & $88 \%$ / 82\% & 12 days & $84 \% / 74 \%$ & 29 days & $84 \% / 73 \%$ \\
\hline \multicolumn{7}{|c|}{ GLT O-Ring Fixtures removed for other reasons } \\
\hline 28 (630 days at $200^{\circ} \mathrm{F}$ ) & 4 hours & $68 \% / 62 \%$ & 10 days & $31 \% / 28 \%$ & 230 days & $28 \% / 24 \%$ \\
\hline $\begin{array}{l}62-2007 \text { ( } \sim 6 \text { months } \\
\left.\text { at } 300^{\circ} \mathrm{F}\right)\end{array}$ & 4 hours & $66 \% / 77 \%$ & 11 days & $35 \% / 35 \%$ & 230 days & $32 \% / 31 \%$ \\
\hline $7\left(2167\right.$ days at $\left.300^{\circ} \mathrm{F}\right)$ & 19 minutes & $93 \% / 84 \%$ & 12 days & $90 \% / 78 \%$ & 29 days & $90 \% / 75 \%$ \\
\hline 30 (1902 days at $\left.300^{\circ} \mathrm{F}\right)$ & 16 minutes & $94 \% / 82 \%$ & 12 days & $90 \% / 73 \%$ & 29 days & $89 \% / 71 \%$ \\
\hline $52\left(1848\right.$ days at $\left.300^{\circ} \mathrm{F}\right)$ & 12 minutes & $92 \% / 87 \%$ & 12 days & $90 \% / 80 \%$ & 29 days & $88 \% / 79 \%$ \\
\hline \multicolumn{7}{|c|}{ GLT-S O-Ring Fixtures removed after failing room temperature leak test } \\
\hline $28 \mathrm{H}\left(50\right.$ days at $\left.400^{\circ} \mathrm{F}\right)$ & 10 minutes & $84 \% / 91 \%$ & 11 days & $80 \% / 88 \%$ & 26 days & $80 \% / 88 \%$ \\
\hline $38 \mathrm{H}\left(358\right.$ days at $\left.350^{\circ} \mathrm{F}\right)$ & 20 minutes & $92 \% / 92 \%$ & 14 days & $90 \% / 88 \%$ & 30 days & $88 \% / 87 \%$ \\
\hline $39 \mathrm{H}\left(114\right.$ days at $\left.350^{\circ} \mathrm{F}\right)$ & 15 minutes & $78 \% / 90 \%$ & 11 days & $74 \% / 89 \%$ & 26 days & $72 \% / 88 \%$ \\
\hline $45 \mathrm{H}\left(99\right.$ days at $\left.400^{\circ} \mathrm{F}\right)$ & 12 minutes & $93 \% / 93 \%$ & 11 days & $91 \% / 92 \%$ & 26 days & $91 \% / 91 \%$ \\
\hline $50 \mathrm{H}\left(281\right.$ days at $\left.400^{\circ} \mathrm{F}\right)$ & 14 minutes & $95 \% / 82 \%$ & 14 days & $93 \% / 76 \%$ & 30 days & $93 \% / 76 \%$ \\
\hline $58 \mathrm{H}\left(75\right.$ days at $\left.400^{\circ} \mathrm{F}\right)$ & 10 minutes & $83 \% / 87 \%$ & 11 days & $81 \% / 84 \%$ & 26 days & $78 \% / 84 \%$ \\
\hline $60 \mathrm{H}\left(50\right.$ days at $\left.400^{\circ} \mathrm{F}\right)$ & 7 minutes & $84 \% / 93 \%$ & 11 days & $80 \% / 90 \%$ & 26 days & $79 \% / 89 \%$ \\
\hline $62 \mathrm{H}\left(50\right.$ days at $\left.400^{\circ} \mathrm{F}\right)$ & 7 minutes & $89 \% / 91 \%$ & 11 days & $86 \% / 89 \%$ & 26 days & $85 \% / 89 \%$ \\
\hline
\end{tabular}

* Compression set is calculated per ASTM D395, Method B, as follows: comp. set $(\%)=\left(\mathrm{t}_{\mathrm{i}}-\mathrm{t}_{\mathrm{f}}\right) /\left(\mathrm{t}_{\mathrm{i}}-\right.$ groove depth $) * 100$

If the initial radial thickness was not recorded, 0.139 inch is assumed. 


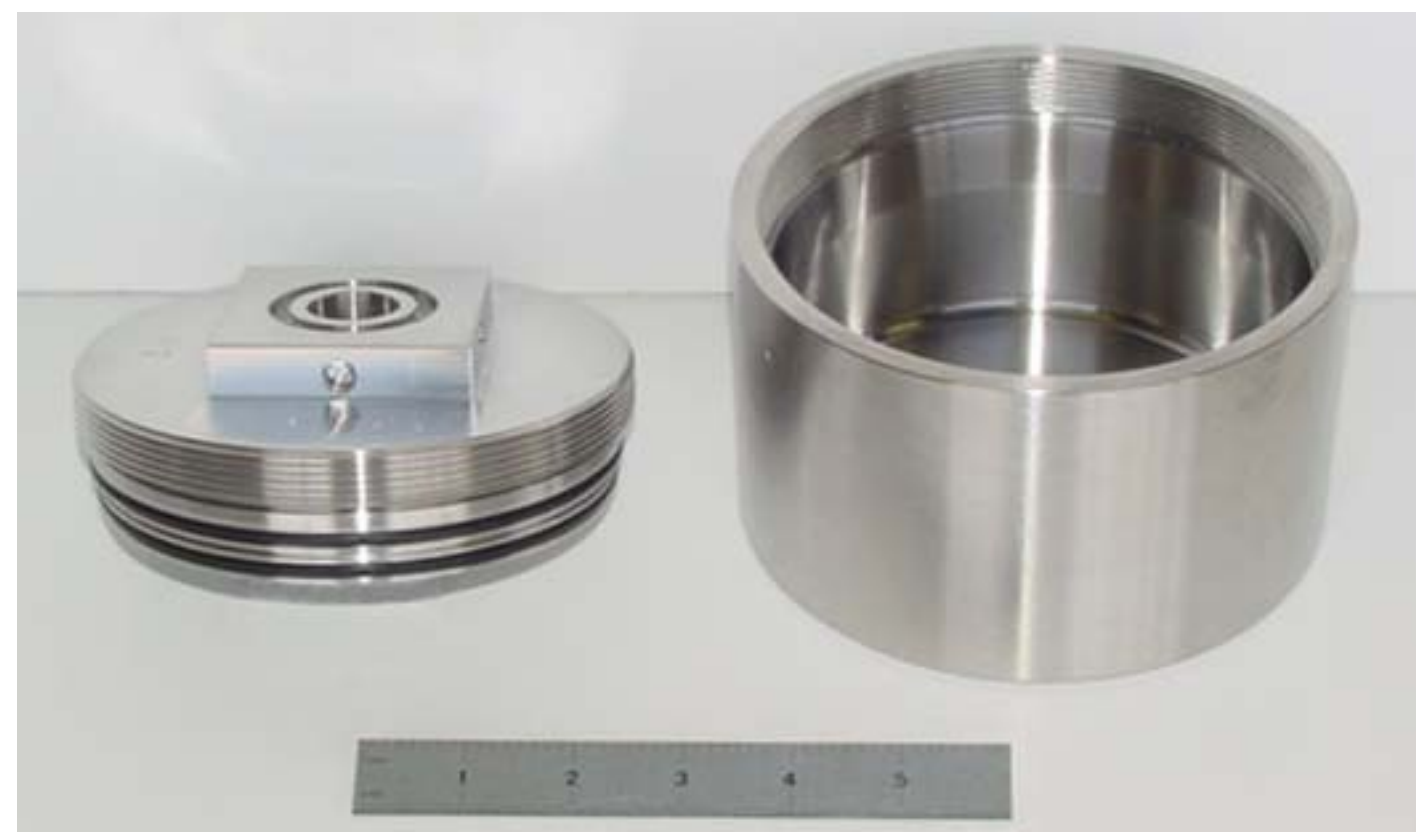

Figure 1. Mock-up PCV test fixture lid and body.

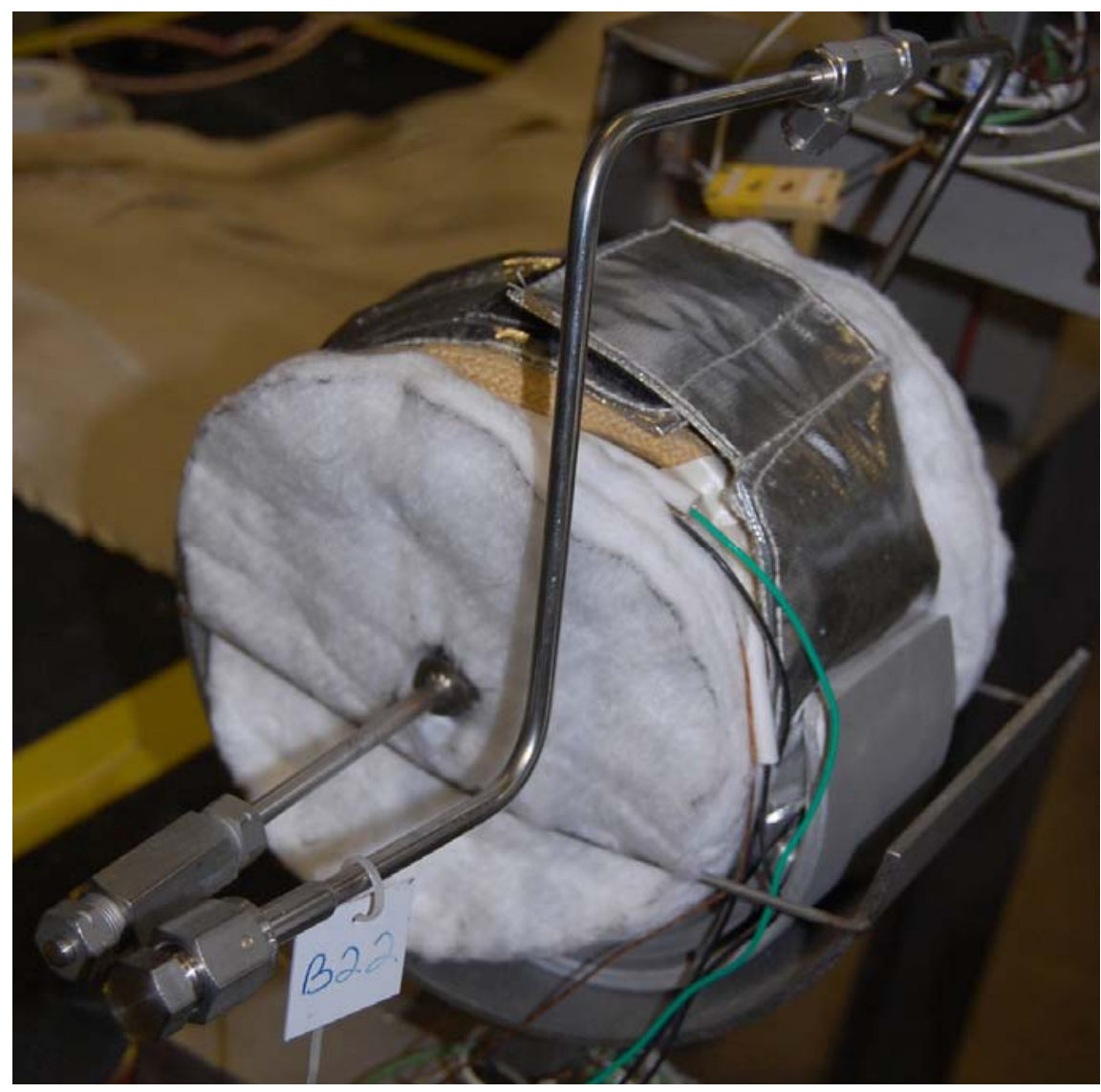

Figure 2. Assembled mock-up PCV. 


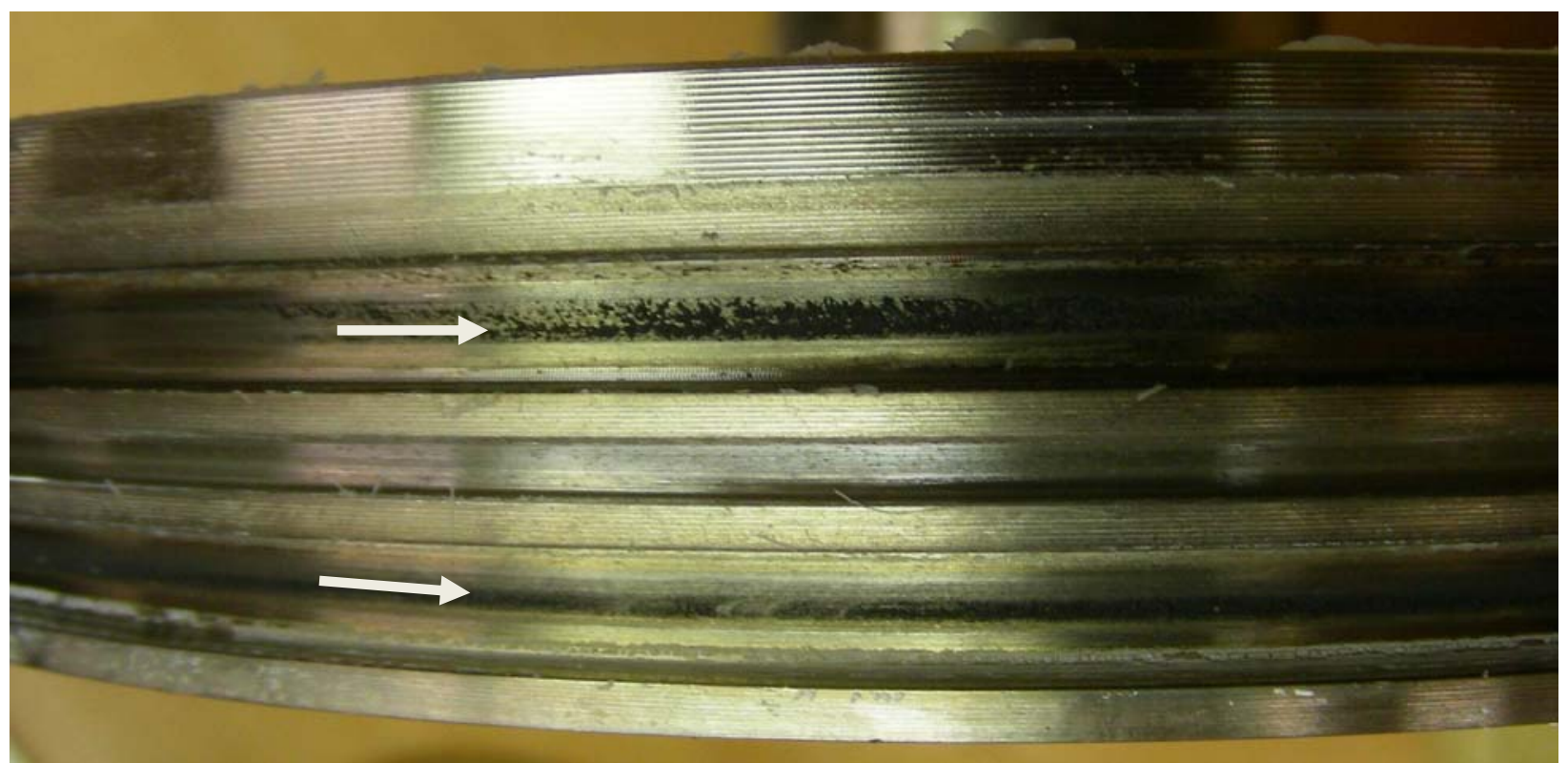

Figure 3. Fixture 7 plug following disassembly, showing O-ring deposits in outer (top) groove and black stain on inner (bottom) groove.

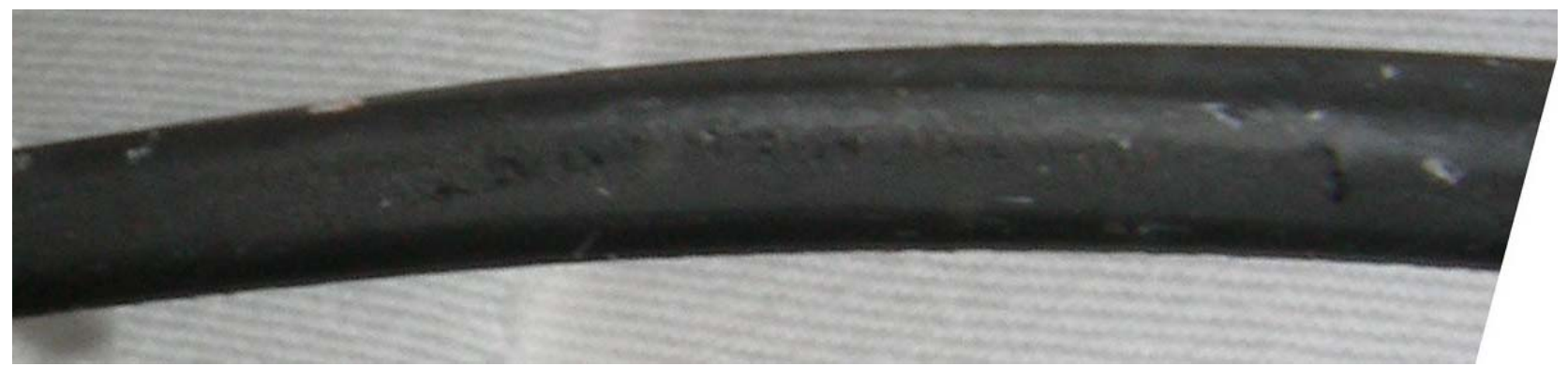

Figure 4. Fixture 7 inner O-ring after removal with pullout.

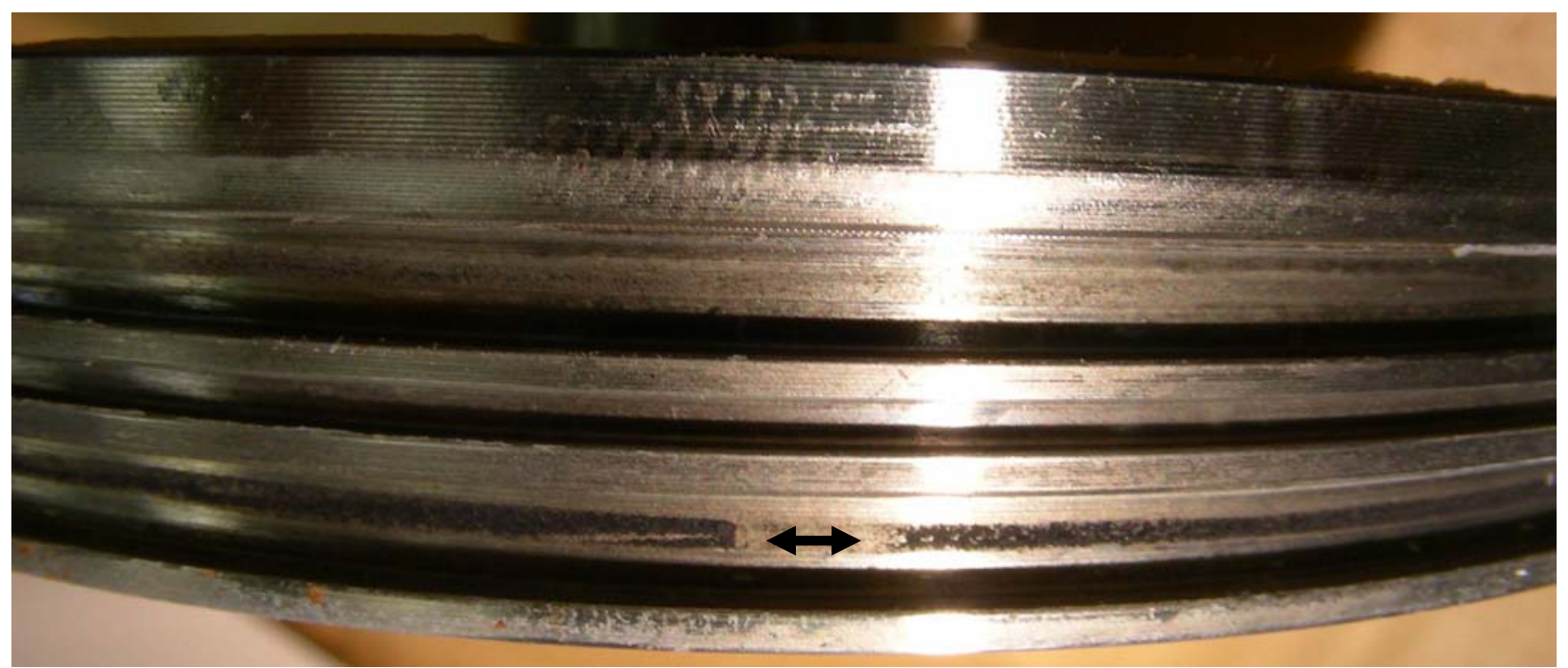

Figure 5. Fixture 52 plug following disassembly, with O-ring deposits in inner (bottom) groove. 
CC: G. A. Abramczyk, 730-A

J. S. Bellamy, 730-A

G. T. Chandler, 773-A

W. L. Daugherty, 773-A

K. A. Dunn, 773-41A

B. A. Eberhard, 105-K

T. W. Griffin, 705-K

E. R. Hackney, 705-K

D. R. Leduc, 730-A

J. W. McEvoy, 707-C

D. L. Melvin, 705-K

T. E. Skidmore, 730-A

K. E. Zeigler, 773-41A

Document Control 